\title{
APLIKASI BIORASIONAL EKSTRAK SIRIH DAN TEMBAKAU PADA PENYAKIT ANTRAKNOSA CABAI DI LAPANG
}

\author{
Application Biorational of Betle And Tobacco Extracts In Antracnose Disease \\ of Chili In Field \\ Oktarina, Bagus Tripama, Alif Darmawan Supartha \\ Prodi Agroteknologi Fakultas Pertanian, Universitas Muhammadiyah Jember \\ E-mail :oktarina@unmuhjember.ac.id
}

\begin{abstract}
ABSTRAK
Penelitian ini bertujuan untuk mengetahui biorasional ekstrak sirih dan tembakau yang efektif dalam menekan penyakit antraknosa cabai. Penelitian ini dilaksanakan di kebun percobaan Fakultas Pertanian Universitas Muhammadiyah Jember. Metode penelitian menggunankan Rancangan Acak Kelompok dengan perlakuan E1 ( kontrol, tanpa perlakuan), E2 (Ekstrak sirih:tembakau 1:1), E3 (Ekstrak Sirih : tembakau 2:1), E4 (Ekstrak Sirih : tembakau 1:2). E5 (Ekstrak Sirih:Tembakau 3:1), E6 (Ekstrak Sirih:Tembakau 1:3) yang masing-masing perlakuan diulang 4 kali. Hasil penelitian menunjukkan bahwa biorasional ekstrak sirih dan tembakau berpengaruh terhadap Intensitas serangan penyakit, Jumlah total buah pertanaman, Jumlah total buah perplot, Berat total buah pertanaman, Berat total buah perplot, Intensitas kerusakan buah perplot.. Biorasional ekstrak sirih dan tembakau 3:1 memberikan efektivitas tebaik.
\end{abstract}

Kata kunci : Cabai merah, ekstrak sirih, ekstrak tembakau dan, Antraknosa

\begin{abstract}
This study aims to determine the biorational of betel and tobacco extracts that are effective in suppressing chili anthracnose disease. This research was carried out in the experimental garden of the Faculty of Agriculture, Muhammadiyah University of Jember. The research method uses a Randomized Complate Block Design, with E1 treatment (control, no treatment), E2 (betel extract: tobacco 1: 1), E3 (Betel Extract: tobacco 2: 1), E4 (Betel Extract: tobacco 1: 2). E5 (Betel Extract: Tobacco 3: 1), E6 (Betel Extract: Tobacco 1: 3), each treatment was repeated 4 times. The results showed that biorational betel extract and tobacco had an effect on disease attack intensity, total number of fruit plantings, total number of plotted fruits, total crop weight, total plot weight, crop damage intensity, damage intensity fruit/plot. Biorational betel and tobacco extracts 3: 1 provide the best effectiveness.
\end{abstract}

Key words : Red chili, Extract of betel Extract of tobacco and, Antraknosa 


\section{PENDAHULUAN}

Antraknosa merupakan penyakit utama tanaman cabai. yang disebabkan oleh jamur Colletotrichum spp. Tanaman yang terinfeksi jamur Colletotrichum spp. dapat menimbulkan gejala berupa bercak atau leiso pada buah yang masih hijau atau yang sudah merah. Bahkan dapat menyerang buah paska panen. Tanaman cabai yang terkena antraknosa dapat menimbulkan kerugian bagi petani cabai, mencapai 80\%. (Syukur, M. et.al., 2009)

Upaya pengendalian berupa pestisida kimia akan menimbulkan berbagai masalah. Penggunaan fungisida sintetik dapat meningkatkan resistensi jamur Colletotrichum Sisa-sisa penggunaan fungisida akan terbuang ke tanah dan perairan sehingga dapat menyebabkan pencemaran lingkungan Ada. 30\% pestisida terbuang ke tanah pada musim kemarau dan $80 \%$ pada musim hujan terbuang ke perairan (Sibarani,2008, Kardinan, 2002). Sehingga diperlukan pestida yang ramah lingkungan yaitu pestisida nabatai (Pesnab)

Pesnab diperoleh dari tumbuhan-tumbuhan yang mengandung metabolit sekunder yang dapat menekan patogen jamur, bakteri dan organisme penggangu tanaman lainnya. (Kardinan, 2002). Tanaman sirih dan tembakau merupakan tanaman yang banyak direkomendasikan sebagai pesnab

. Daun sirih (Piper betle L.) termasuk dalam famili piperaceae (sirih-sirihan) yang mengandung minyak atsiri dan senyawa alkaloid (Nurhayati, et al, 2011). sirih berfungsi sebagai anti jamur, yang dapat mempengaruhi pertumbuhan dan pembentukan konodia jamur (Oktarina et al. 2017a). Tanaman sirih banyak ditanam masyrakat sebagai tanaman obat, sehingga mudah didapatkan.. Penelitian Oktarian et.al. 2017. Ekstrak sirih dapat menghambat pertumbuhan koloni dan konida jamur Colletotrichum secara invitro

Tembakau merupakan salah satu komoditas perkebunan penting di Indonesia, khususnya kabupaten Jember. Tembakau tidak hanya sebagai bahan pengisi rokok tapi juga banyak manfaat tembakau lainnya. Tembakau mengandung nicotin, alkoloid yang dapat digunakan sebagai pesnab. Nikotin juga 
dapat dipakai sebagai fungisida.( Novizan, 2002 dalam Nurnasari, 2011). Nikotin memiliki fungsi dalam menghambat pertumbuhan fungi. Hal ini berkaitan dengan fungsi nikotin dalam menghambat kerja enzim .Selain itu tembakau mengandung senyawa golongan fenol yaitu, Senyawa flavonoid., yang berfungsi merusak dinding sel jamur. Flavonoid dapat berikatan dengan dinding sel melalui sebuah kompleks protein-fenol, yang melibatkan adanya ikatan hidrogen antara protein dan fenol. Kompleks ini nantinya akan dapat menyebabkan kerusakan (denaturasi) ikatan hidrogen dalam protein pada dinding sel jamur. Selanjutnya, kerusakan inilah yang membuat matriks intraseluler jamur keluar. Keluarnya matriks ini menyebabkan kematian sel jamur (Obongoya, et al. 2010).

Osmotin merupakan kandungan lain yang terdapat dalam tembakau yang memiliki efek fungisidal terhadap beberapa jenis fungi patogen. Osmotin ini memiliki fungsi dalam menghambat pembentukan dan pertumbuhan fungi pada tahap pembentukan spora. Osmotin memiliki fungsi dalam melemahkan dinding sel fungi, dapat mengganggu sintesis dinding sel fungi dan secara umum dapat menghambat pembentukan RNA pada saat sintesis protein pada fungi (Abad, et al,. 1996).

Campuran ekstrak sirih dan tembakau akan memberikan efektivitas yang tinggi terhadap OPT tanaman cabai. Biorasional ekstrak sirih dan tembakau merupakan perbandingan jumlah ekstrak sirih dan tembakau yang dicampurkan untuk diplikasikan ke pertanaman cabai.

Penelitian Oktarina. et al (2017b) Biorasional sirih :tembakau 3:1 memberikan daya hambat tertinggi terhadap Colletotrichum sp. secara invitro. Selain itu juga dapat menunda masa inkubasi patogen pada buah cabai pasca panen di laboratorium.

Penelitian ini bertujuan untuk mengetahui biorasional ekstrak sirih dan tembakau terbaik dalam menekan intensitas penyakit antraknosa di lapang. dan biorasional ekstrak sirih dan tembakau yang efektiv dalam meningkatkan produksi cabai 


\section{METODE PENELITIAN}

Penelitian ini dilaksanakan pada bulan Juli sampai September 2017 di Kebun Percobaan Fakultas Pertanian Universitas Muhammadiyah Kabupaten Jember. Dengan ketinggian tempat \pm 89 meter dpl. .Alat dan bahan yang digunakan Bahan, benih cabai varietas Ballebat, pupuk kompos dan NPK, ekstrak tembakau dan ekstrak sirih.Sedangkan alat yang digunakan yaitu traktor, cangkul, timba, gembor, penggaris, timbangan, botol semprot, sabit, mesin pemotong rumput, dan alat lainnya yang di perlukan selama proses penelitian berlangsung

Penelitian menggunakan metode Rancangan Acak Kelompok, dengan perlakuan E1 ( kontrol, tanpa perlakuan), E2 (Ekstrak sirih : :tembakau 1:1), E3 (Ekstrak Sirih : tembakau 2:1), E4 (Ekstrak Sirih : tembakau 1:2). E5 (Ekstrak Sirih:Tembakau 3:1), E6 (Ekstrak Sirih:Tembakau 1:3). Masing-masing perlakuan diulang 4 kali.

Persiapan Lahan diukur dan dibagi menjadi 24 plot dengan luas masingmasing plot $2 \times 2$ dengan jarak antar plot $50 \mathrm{~cm}$.

Pemasangan mulsa di lakukan secara bersamaan pertama dilakukan penanaman cabai merah pada plot dengan jarak antar lubang tanam $30 \mathrm{~cm}$ setelah kacang tanah berumur 21-24 hst

Penanaman dilakukan dengan jarak atar tanam $50 \mathrm{~cm}$ x $50 \mathrm{~cm}$, setiap lubang tanam diberikan 1 bibit cabai merah setelah itu disiram dengan air.Pemupukan dilakukan 5x dengan interval 10 hari (umur, 31, 41, 51, 61 dan 71 hst) dengan dosis $3 \mathrm{~g}$ NPK/tanaman.

Pengedalian hama dan penyakit menggunakan pestisida nabati biorasional ekstrak sirih dan tembakau sesuai perlakuan yang disemprot 5 hari sekali dengan konsentrasi 50\%. Pembuatan ekstrak daun sirih (ES) dilakukan dengan meblender $1 \mathrm{~kg}$ daun sirih dalam $1 \mathrm{lt}$ air, lalu disaring (sebagai larutan stok). Untuk mendapatkan konsentrasi 50\% maka $500 \mathrm{ml}$ ekstrak yang sudah disraing (larutan stok) dilarutkan dalam $1000 \mathrm{ml}$ air. Begitupun untuk ekstrak daun tembakau (ET) $1 \mathrm{~kg}$ daun tembakau diblender dalam 11 air kemudian disaring (larutan stok). Lalu diencerkan 50\% dengan menambahkan 1 lt air dalam $500 \mathrm{ml}$ larutan stok. 
Untuk mendapatkan biorasional $1: 1,1 ; 2 ; 2: 1 ; 3 ; 1$ dan 1:3. Maka dilakukan pencampuran ES dan ET yang sudah diencerkan dengan volume sesuai rasio perlakuan E1 (tanpa ekstrak); E2 $(1: 1=500 \mathrm{ml} \mathrm{ES}+500 \mathrm{ml}$ ET); E3 ( 2:1 = 666,67 ml ES + 333,33 ml ET ); E4 ( 1:2 = 333,33 ml ES + 666,67 ml ET), E5 $(3: 1=750 \mathrm{ml} \mathrm{ES}+250 \mathrm{ml} \mathrm{ET}), \mathrm{E} 6(1: 3=250 \mathrm{ml} \mathrm{ES}+750 \mathrm{ml} \mathrm{ET})$

Pemanenan dilakuakan 5x dengan interval 5-7 hari, buah dipetik yang sudah siap dikonsumsi baik buah yang sehat maupun buah yang rusak dengan tingkat kematangan $50 \%$.

Tanaman dipanen dalam penelitian diambil sebanyak 5 sempel dari semua Parameter pengamatan yaitu ; (1) Intensitas serangan penyakit , (2) Jumlah total buah pertanaman, (3) Jumlah total buah perplot , (4) Berat total buah pertanaman (5) Berat total buah perplot, (6) Intensitas kerusakan buah pertanaman, (7) Intensitas kerusakan buah perplot, (8) Jumlah total buah sehat pertanaman,(9) Jumlah total buah sehat perplot

Data di analisis dan menggunakan analisis Varian (Uji F) pada taraf kepercayaan 95\%, Jika menunjukkan beda nyata dari Uji F maka di lanjudkan dengan Uji jarak berganda Duncan dengan taraf kepercayaan 95\%.

\section{HASIL DAN PEMBAHASAN}

Hasil penelitian tentang aplikasi biorasional ekstrak sirih dan tembakau terhadap penyakit antraknosa tanaman cabai,dianalisis dengan menggunakan analisis ragam Uji F . Uji lanjut dengan uji jarak berganda Duncan untuk mengetahui pengaruh terbaik. Adapun rangkuman analisi ragam pada masingmasing variabel pengamatan disajikan pada Tabel 1 .

Table 1. Rangkuman hasil analisis ragam terhadap semua variabel pengamatan.

\begin{tabular}{lc}
\hline \multicolumn{1}{c}{ Variabel } & F Hitung \\
\hline Intensitas Serangan Penyakit & $29,017^{* *}$ \\
Jumlah Total Buah per Tanaman & $17,755^{* *}$ \\
Jumlah Total Buah per Plot & $15,795^{* *}$ \\
Berat Total Buah per Tanaman & $6637,02^{* *}$ \\
Berat Total Buah per Plot & $9417,54^{* *}$ \\
Intensitas kerusakan Buah per Tanaman & $72,983^{* *}$ \\
Intensitas Kerusakan Buah per plot & $186,18^{* *}$ \\
\hline Keterangan = ns : Tidak Berbeda Nyata, *: Berbeda Nyata, **: Berbeda Sangat Nyata
\end{tabular}




\section{Intensitas Serangan Penyakit}

Hasil analisi ragam intensitas serangan penyakit menunjukkan bahwa perlakuan biorasional ekstrak sirih dan ekstrak tembakau berbeda sangat nyata (tabel 1). Hasil uji lanjut dengan uji Duncan hal ini disajikan pada tabel 2.

Tabel 2. Pengaruh efektivitas biorasional ekstrak sirih dan tembakau terhadap intensitas serangan penyakit tanaman cabai

\begin{tabular}{lc}
\hline Biorasional Ekstrak Sirih dan Ekstrak Tembakau & $\begin{array}{c}\text { Intensitas Serangan } \\
\text { Penyakit(\%) }\end{array}$ \\
\hline E 1 Tanpa Ekstrak & $46 \mathrm{~d}$ \\
E2 Ekstrak Sirih dan Ekstrak Tembakau (1:1) & $31 \mathrm{c}$ \\
E3 Ekstrak Sirih dan Ekstrak Tembakau (2:1) & $26 \mathrm{~b}$ \\
E4 Ekstrak Sirih dan Ekstrak Tembakau (1:2) & $30 \mathrm{c}$ \\
E5 Ekstrak Sirih dan Ekstrak Tembakau (3:1) & $21 \mathrm{a}$ \\
E6 Ekstrak Sirih dan Ekstrak Tembakau (1:3) & $25 \mathrm{~b}$ \\
\hline
\end{tabular}

Keterangan : Angka-angka yang disertai dengan huruf yang sama menunjukkan berbeda tidak nyata menurut uji jarak berganda Duncam taraf 5\%.

Pada Tabel 2. Menunjukkan bahwa biorasional ekstrak sirih dan ekstrak tembakau pada uji jarak berganda Duncan menunjukkan bahwa perlakuan tanpa ektrak intensitas penyakit pada tanaman paling tinggi yaitu $46 \%$ yang berbeda nyata dibandingkan dengan perlakuan biorasional ekstrak sirih dan tembakau. Pada biorasional ekstrak sirih tembakai 3:1 (E5) memberikan pengaruh terbaik dengan intensitas penyakit paling rendah $(21 \%)$ dibandingkan perlakuan yang lain.

Gejala serangan penyakit antraknosa pada tanaman mudah terlihat oleh adanya ciri berupa bercak bulat panjang,berwarna merah kecoklatan dengan meninggalkan sepanjang bercak luka.Infeksi ini terjadi dalam lokasi potongan kecil yang tersebar kemana-mana dan menyerang daun (Dehne, et al. 1997).

Bercak berkembang cepat pada musim hujan, bahkan pada lingkungan yang kondusif penyakit ini dapat menghancurkan seluruh areal pertanaman cabai (Syukur, 2007).

Birasional sirih dan tembakau dengan ekstrak sirih yang lebih tinggi dapat menekan intansitas penyakit antraknosa lebih baik. Komponen kimia daun sirih adalah minyak atsiri, seskuiterpen, triterpen, terponoid, sitosterol, neolignan dan 
krotepoksid. Aktivitas antifungi diduga berasal dari minyak atsiri daun sirih yaitu isocugemol, limonene dan kariefilena dan juga ada di tembakau (Hertiana dan Purwanti,2002).

\section{Jumlah Total Buah Pertanaman}

Hasil analisi ragam Jumlah total buah pertanaman menunjukkan bahwa perlakuan biorasional ekstrak sirih dan tembakau berbeda sangat nyata (tabel 1). Hasil uji lanjut dengan uji Duncan hal ini disajikan pada tabel 3.

Tabel 3. Pengaruh efektivitas biorasional ekstrak sirih dan tembakau terhadap jumlah total buah pertanaman.

\begin{tabular}{lc}
\hline \multicolumn{1}{c}{ Biorasional Ekstrak Tembakau dan Ekstrak Sirih } & $\begin{array}{c}\text { Jumlah Total Buah } \\
\text { Pertanaman (buah) }\end{array}$ \\
\hline E 1 Tanpa Ekstrak & $31,7 \mathrm{e}$ \\
E2 Ekstrak Sirih dan Ekstrak Tembakau (1:1) & $35,6 \mathrm{c}$ \\
E3 Ekstrak Sirih dan Ekstrak Tembakau (2:1) & $37,0 \mathrm{~b}$ \\
E4 Ekstrak Sirih dan Ekstrak Tembakau (1:2) & $34,6 \mathrm{~d}$ \\
E5 Ekstrak Sirih dan Ekstrak Tembakau (3:1) & $41,1 \mathrm{a}$ \\
E6 Ekstrak Sirih dan Ekstrak Tembakau (1:3) & $36,1 \mathrm{c}$ \\
\hline
\end{tabular}

Keterangan : Angka-angka yang disertai dengan huruf yang sama menunjukkan berbeda tidak nyata menurut uji jarak berganda Duncam taraf 5\%.

Pada Tabel 3. menunjukkan bahwa biorasional ekstrak sirih dan tembakau berpengaruh terhadap jumlah buah cabai dibandingkan tanpa pemberian ekstrak sirih dan tembakau. Biorasonal ekstrak sirih dan tembakau yang berbeda juga menghasilkan jumlah buah yang berbeda nyata.

Biorasinal ekstrak sirih dan tembakau 3:1 (E5) memberikan hasil terbaik yaitu 41 buah pertanaman yang berbeda dibandingkan biorasional yang lain. Apalagi tanpa perlakuan jumlah buah pertanaman hanya 32 buah..

Intensitas penyakit yang rendah pada perlakuan biorasional 3:1 (tabel 2) akan memberikan pertumbuhan dan hasil yang baik yang ditunjukkan pada indikator jumlah buah pertanman yang tinggi 


\section{Jumlah Total Buah Plot}

Hasil analisi ragam Jumlah total buah perplot menunjukkan bahwa perlakuan biorasional ekstrak sirih dan tembakau berbeda sangat nyata (tabel 1). Hasil uji lanjut dengan uji Duncan hal ini disajikan pada tabel 4.

Tabel 4. Pengaruh efektivitas biorasional ekstrak sirih dan ekstrak tembakau terhadap jumlah total buah per plot.

\begin{tabular}{|c|c|}
\hline Biorasional Ekstrak Sirih dan Ekstrak Tembakau & $\begin{array}{c}\text { Jumlah Total Buah } \\
\text { Plot (buah) }\end{array}$ \\
\hline E 1 Tanpa Ekstrak & $70,3 \mathrm{~d}$ \\
\hline E2 Ekstrak Sirih dan Ekstrak Tembakau (1:1) & $76,7 \mathrm{c}$ \\
\hline E3 Ekstrak Sirih dan Ekstrak Tembakau (2:1) & $78,2 \mathrm{~b}$ \\
\hline E4 Ekstrak Sirih dan Ekstrak Tembakau (1:2) & $77,1 \mathrm{c}$ \\
\hline E5 Ekstrak Sirih dan Ekstrak Tembakau (3:1) & 80,9 a \\
\hline E6 Ekstrak Sirih dan Ekstrak Tembakau (1:3) & $79,2 \mathrm{~b}$ \\
\hline
\end{tabular}

Keterangan : Angka-angka yang disertai dengan huruf yang sama menunjukkan berbeda tidak nyata menurut uji jarak berganda Duncam taraf 5\%.

Pada Tabel 4. Menunjukkan bahwa perlakuan biorasional ekstrak sirih dan tembakau berbeda nyata dibandingkan tanpa perlakuan ekstrak. Antara biorasional ekstrak sirih dan tembakau juga berbeda nyta terhadap jumlah buah perplot.

Perlakuan ekstrak sirih dan tembakau 2: 1 memberikan hasil lebih baik dibandingkan tanpa perlakuan (E1) dan perlakauan E2 (ES;ET 1;1) dan E4 $(\mathrm{ES} ; \mathrm{ET}=1: 2)$. Sedangkan perlakuan E5 (ES:ET = 3:1) memberikan hasil jumlah buah perplot paling tinggi ( 81 buah) dibandingkan perlakuan yang lain.

Perlakuan biorasional ektrak sirih dan tembakau (3:1) dengan jumlah buah perplot tertinggi didukung dari variabel intensitas penyakit yang rendah dan jumlah buah Pertanaman yang juga tinggi

\section{Berat Total Buah Per Tanaman}

Hasil analisi ragam berat total buah pertanaman menunjukkan bahwa perlakuan ekstrak tembakau dan ekstrak sirih berbeda sangat nyata (tabel 1). Hasil uji lanjut dengan uji Duncan terhadap berat total buah per tanaman pada tabel 5 . 
Pada Tabel 5. Menunjukkan bahwa biorasional ekstrak sirih dan tembakau berbedanyata terhadap berabiorasionalt buah pertanaman dibandingkan tanpa perlakuan ekstrak. Perlakuan biorasional ekstrak sirih dan tembakau E3 (2:1 ) memberikan hasil yang sama dengan perlakuan E6 (1:3) tapi hasilnya lebih baik dibandingkan dengan perlakuan biorasional E2 (1:1) dan E4(1:2)

Tabel 5. Pengaruh efektivitas biorasional ekstrak sirih dan ekstrak tembakau terhadap berat total buah pertanaman.

\begin{tabular}{lc}
\hline \multicolumn{1}{c}{ Biorasional Ekstrak Sirih dan Ekstrak Tembakau } & $\begin{array}{c}\text { Berat Total Buah } \\
\text { per Tanaman }(\mathrm{g})\end{array}$ \\
\hline E 1 Tanpa Ekstrak & $268,24 \mathrm{~d}$ \\
E2 Ekstrak Sirih dan Ekstrak Tembakau (1:1) & $318,82 \mathrm{c}$ \\
E3 Ekstrak Sirih dan Ekstrak Tembakau (2:1) & $342,72 \mathrm{~b}$ \\
E4 Ekstrak Sirih dan Ekstrak Tembakau (1:2) & $310,98 \mathrm{c}$ \\
E5 Ekstrak Sirih dan Ekstrak Tembakau (3:1) & $384,51 \mathrm{a}$ \\
E6 Ekstrak Sirih dan Ekstrak Tembakau (1:3) & $333,99 \mathrm{~b}$ \\
\hline
\end{tabular}

Keterangan : Angka-angka yang disertai dengan huruf yang sama menunjukkan berbeda tidak nyata menurut uji jarak berganda Duncam taraf $5 \%$.

Perlakuan biorasional E5 (3:1) memberikan hasil berat buah terbaik dengan berat tertinggi yaitu 384,51 g/tanaman dan ini berbeda nyata dibandingkan dengan perlakuan yang lain. Perlakuan E5 memberikan berat terbaik, hal ini didukung rendahnya intensitas penyakit antraknosa tanaman cabai (tabel 2) dan juga didukung oleh jumlah buah pertanaman yang tertinggi (tabel 3).

\section{Berat Total Buah PerPlot}

Hasil analisi ragam berat total buah plot menunjukkan bahwa perlakuan ekstrak sirih dan ekstrak tembakau berbeda sangat nyata (tabel 1). Hasil uji lanjut dengan uji Duncan terhadap berat total buah per tanaman pada tabel 6 .

Pada Tabel 6. Dapat diketahui bahwa perlakuan biorasional ekstrak sirih dan tembakau berbeda nyata dibandingkan tanpa perlakuan (E1) pada variabel berat buah perplot. Biorasional ekstark sirih dan tembakau 2:1 (E3) memberikan berat buah perplot yang tidak berbeda nyta dengan perlakuan biorasinal 1:3 (E6) tapi berbeda nyata diabndingkan biorasinal 1:1 (E2) dan 1:2 (E4) sedangkan biorasional ekstrak sirih dan tembakau 3:1 (E5) memberikan hasil yang terbaik dengan berat buah perplot tertinggi yaitu 895,40 g/plot. 
Tabel 6. Pengaruh efektivitas biorasional ekstrak sirih dan tembakau terhadap berat total buah perplot.

\begin{tabular}{lc}
\hline \multicolumn{1}{c}{ Biorasional Ekstrak Sirih dan Ekstrak Tembakau } & $\begin{array}{c}\text { Berat Total Buah } \\
\text { perplot }(\mathrm{g})\end{array}$ \\
\hline E 1 Tanpa Ekstrak & $664,95 \mathrm{~d}$ \\
E2 Ekstrak Sirih dan Ekstrak Tembakau (1:1) & $758,35 \mathrm{c}$ \\
E3 Ekstrak Sirih dan Ekstrak Tembakau (2:1) & $812,75 \mathrm{~b}$ \\
E4 Ekstrak Sirih dan Ekstrak Tembakau (1:2) & $757,90 \mathrm{c}$ \\
E5 Ekstrak Sirih dan Ekstrak Tembakau (3:1) & $895,40 \mathrm{a}$ \\
E6 Ekstrak Sirih dan Ekstrak Tembakau (1:3) & $797,35 \mathrm{~b}$ \\
\hline
\end{tabular}

Keterangan : Angka-angka yang disertai dengan huruf yang sama menunjukkan berbeda tidak nyata menurut uji jarak berganda Duncam taraf $5 \%$.

Aplikasi pestisida nabati dengan biorasinal ekstrak sirih dan tembakau 3:1 memberikan pertumbuhan perkembangan tanaman yang baik. Tanaman atau tumbuhan ini jarang diserang oleh hama sehingga banyak digunakan sebagai ekstrak pestisida nabati dalam pertanian organik (Hasyim, A. dkk, 2010) sehingga akan memberikan produksi perplot yang tinggi. Intensitas penyakit yang rendah akan memberikan jumlah buah perplot juga tinggi. Jumlah buah yang banyak akan memberikan berat buah perplot yang tinggi..

\section{Intensitas kerusakan Buah Per Plot}

Hasil analisi ragam menunjukkan bahwa perlakuan ekstrak sirih dan tembakau berbeda sangat nyata (tabel 1). Hasil uji lanjut dengan uji Duncan terhadap Intensitas kerusakan buah per plot pada tabel 7.

Intensitas kerusakan buah perplot terjadi pada perlakuan tanpa ekstrak (E1) mencapai 34\%. Sedangkan perlakuan aplikasi biorasional ekstrak sirih dan tembakau memberikan intensitas kerusakan buah berbeda nyata dibanding dengan tanpa ekstrak. Biorasional ekstrak sirih dan tembakau 2:1 memberikan hasil yang sama terhadap intensitas kerusakan buah pada perlakuan 1:3 (E 6) tapi ini lebih baik dibandingkan dengan perlakuan E2 (1:1) dengan intensitas kerusakan mencapai $18 \%$. 
Tabel 7 Aplikasi biorasional ekstrak sirih dan tembakau terhadap Intensitas kerusakan buah per plot.

\begin{tabular}{|c|c|}
\hline Biorasional Ekstrak Sirih dan Ekstrak Tembakau & $\begin{array}{c}\text { Intensitas kerusakan } \\
\text { buah per plot }(\%)\end{array}$ \\
\hline E 1 Tanpa Ekstrak & $34 d$ \\
\hline E2 Ekstrak Sirih dan Ekstrak Tembakau (1:1) & $18 \mathrm{c}$ \\
\hline E3 Ekstrak Sirih dan Ekstrak Tembakau (2:1) & $12 b$ \\
\hline E4 Ekstrak Sirih dan Ekstrak Tembakau (1:2) & $15 \mathrm{c}$ \\
\hline E5 Ekstrak Sirih dan Ekstrak Tembakau (3:1) & $6 a$ \\
\hline E6 Ekstrak Sirih dan Ekstrak Tembakau (1:3) & $11 \mathrm{~b}$ \\
\hline
\end{tabular}

Keterangan : Angka-angka yang disertai dengan huruf yang sama menunjukkan berbeda tidak nyata menurut uji jarak berganda Duncam taraf $5 \%$.

Biorasional ekstrak sirih dan tembakau 3:1 (E5) memberikan intensitas penyakit antraknosa pada buah cabai paling rendah yaitu $6 \%$. Ini menunjukkan tanaman cabai yang terinfeksi jamur Colletotrichum sp. penyebab antraknosa dapat ditekani dengan penyemprotan pestisida nabati ekstrak sirih dan tembakau 3:1. Sedangkan tanpa aplikasi pestisida nabati dapat menyebabkan intensitas kerusakan buah mencapai 34\%. Bahkan bisa mencapai kerugian sebesar $60 \%$ (Duriat dkk., 1991; Hartman \& Wang, 1992 dalam Setyowati dkk., 2007). Bahkan apabila tidak dilakukan pengendalian secara tepat kehilangan hasilnya mencapai 100\% (Duriat dkk., 2007)

\section{KESIMPULAN DAN SARAN}

\section{Kesimpulan}

1. Aplikasi biorasional ekstrak sirih dan tembakau berpengaruh terhadap intansitas penyakit antraknosa tanaman dan buah cabai. Biorasinal ekstrak sirih tembakau 3:1 memberikan penekan yang terbaik terhadap intensitas penyakit pada tanaman dan buah cabai.

2. Aplikasi biorasinal ekstrak sirih dan tembakau berpengaruh nyata terhadap produksi cabai. Perlakuan biorasional ekstrak sirih dan cabai 3:1 merupakan biorasional yang paling tepat yang dapat memberikan produksi buah cabai terbaik. 


\section{Saran}

Berdasarkan hasil percobaan diperoleh perbandingan terbaik biorasional ekstrak tembakau dan esktrak sirih pada tanaman cabai merah (1:3) yang dapat menekan dan mencegah perkembangan penyakit antraknosa

\section{DAFTAR PUSTAKA}

Abad, L. R., D’ Urzo, M.P., Liu D, Narasimhan, M.L, Reuveni, M., Zhu, K. J., Niu, X., Singh N. K., Hasegawa P, M. \& Bressan, R. A. 1996. Antifungal Activity of Tobacco Osmotin has Specifity and Involves Plasma Membrane Permeabilization.Proc. Natl. Acad. Sci. USA. Vol.94.

Denhe,W.H, Adam, G, Diekmann, M, Frehm.J, Machnik, M.A., and Halteren,V.P., 1997. Diagnosis and identification of Plant Pathogends,Kluwer Academic Publisher,London

Duriat, A.S., Gunaeni, N, dan Wulandari, A. W. 2007.Penyakit Penting Pada Tanaman Cabai dna Pengendaliannya Balai Penelitian Tanaman Sayuran . Bandung. 55 hlm.

Elfina, dkk. 2015. Uji Beberapa Konsentrasi Ekstrak Tepung Daun Sirih Hutan (Piper Aduncum L.) Untuk Mengendalikan Penyakit Antraknosa Pada Buah Cabai Merah Pasca Panen. Jurusan Agroteknologi. Fakultas Pertanian. Universitas Riau, Pekanbaru.

Hasyim, A, W Setiawati, dan L Lukman. 2015.Inovasi teknologi pengendalian OPT ramah lingkungan pada cabai: Upaya alternatif menuju ekosistem harmonis. Pengembangan Inovasi Pertanian. 8 (1): 1-10

Hertiana, T. dan Purwati. 2002. Minyak Atrisi Hasil Destalasi Ekstrak Etanol daun Sirih (Piper betle L) beberapa daerah di Yogyakarta. Yogyakarta.

Kardinan, A., 2002.Pestisida Nabati. Penebar Swadaya Jakarta

Nalina, Y and Z.H.A Rahim, 2006. Effect of Piper betle L. Leat extract the Virulence J. Agroteknos

Ningtyas, I.R. 2013. Pengaruh berbagai tingkat fraksi daun sirih(Piper betle L.) dan daun babadotan (Ageratuum conyzoides) terhadap Colletotrichum capsici penyebab penyakit antraknosa pada cabai (Capsicum annum L) secara In vitro. Skripsi. Universitas Lampung.Bandar Lampung. 
Nurnasari , E dan Subyakto. 2011. Komposisi Kimia Minyak Atsiri Pada Beberapa Tipe Daun Tembakau (Nicotiana Tabaccum L.), Balai Penelitian Tanaman Tembakau dan Serat, Malang

Nurmansyah. 1997. Kajian awal potensi gulma sirih-sirih (Piper aduncum L.) sebagai fungisida nabati. Jurnal StigmaAn Agricultural Science Journal

Nurhayati. 2011. Efetivitas Ekstrak Daun Sirih Terhadap Infeksi Colletotrichum capsici Pada Buah Cabai. Dharmapala, Volume 3, No. 2. Fakultas Pertanian, Universitas Sriwijaya, Sumatera Selatan.

Obongoya BO, Wagai SO, Odhiambo G. 2010. Phytotoxic effect of selected crude plant extracts on soil-borne fungi of common bean. African Crop Sci J. 18(1): 15-22.

Oktarina, B.Tripama, 2017a. Ekstrak sirih dan Tembakau sebagai Fungisida Nabati pada Penyakit Antraknosa Cabai Yang disebabkan Colletotrichum. Prosiding Seminar Nasioanl Hasil Penelitian Pertanian VII. UGM. Yogyakarta

Oktarina, Tripama B., Rohmah ,W.N., 2017b Daya Hambat Ekstrak Sirih dan Tembakau Pada Colletotrichum capsici Penyebab Antraknosa Cabai.. Jurnal Agritrop Vol 15 (2) Fakultas Pertanian Universitas Muhammadiyah Jember

Rohmawati, A., 2002. Pengaruh Kerapatan Sel dan Macam Agensia Hayati Terhadap Perkembangan Penyakit Antraknosa dan Hasil Tanaman Cabai (Capsicum annum L.).

Sibarani. M. Friska. (2008). Uji Efektifitas Beberapa Pestisida Nabati untuk Mengendalikan Penyakit Antraknosa (Colletotrichum capsici) pada Tanaman Cabai (Capsicum annum L) di Lapangan .[Skripsi]. Medan : Fakultas Pertanian, Universitas Sumatra Utara.

Syukur, M., S. Sujiprihati, J. Koswara dan Widodo. 2009. Ketahanan terhadap Antraknosa yang Disebabkan oleh Colletotrichum acutatum pada Beberapa Genotipe Cabai (Capsicum annuum L.) dan Korelasinya dengan Kandungan Kapsaicin dan Peroksidase. J. Agron. Indonesia 37 (3) : 233 239 (2009). 